\title{
PREDICTION OF THE DURATION OF HOSPITAL TREATMENT OF PATIENTS WITH CATARACT
}

\author{
Mihail Kovtun \\ MIHP "Kharkiv Municipal Clinical Hospital \# 14 named by Prof. L. L. Hirshman" \\ 5 Oles' Honchiar str., Kharkiv, Ukraine, 61023 \\ mik_60@mail.ru \\ Marina Kochina \\ Department of Clinical Informatics and Informative Technologies of Health \\ Kharkiv Medical Academy of Postgraduate Education \\ 58 Amosova str., Kharkiv, Ukraine, 61176 \\ kochinam@inbox.ru \\ Inna Lapkina \\ Department of Ophthalmology \\ Kharkiv Medical Academy of Postgraduate Education \\ 58 Amosova str., Kharkiv, Ukraine, 61176 \\ innalapkina@mail.ru
}

Abstract

The aim of the paper was to evaluate and determine the duration of the hospital treatment of patients with cataract.

Materials and methods of the investigation. 629 case histories were analyzed and 60 patients' forms were also analyzed. The assessment of case histories was done according to the scheme: sex, age, the stage of cataract, the duration of hospital treatment, the cause of treatment which lasts more than 1 day (postoperative complication, treatment of concomitant eye diseases, patient's desire), the type of complication. 60 surveyed patients with cataract required surgical treatment in order to work out the model of the duration of hospital treatment. The questionnaire contained several questions, which answers allow evaluating the social status of patients, somatic and optic status, peculiarities of the main disease and also the duration at the hospital after the operation.

Results. It has been demonstrated that patient's age, his or her financial status, the number of concomitant somatic and eye diseases are the main peculiarities for the prognosis for long-lasting stay at hospital after surgical treatment. Undetermined logics was used to create the model of prognosis of the duration of hospital treatment based on epy results of patients' questionnaire, the method of clustering was used to receive undetermined rules.

Conclusions. Ophthalmologic status of the patient, the presence of concomitant eye diseases, such as myopia alta, glaucoma, diseases of retina, and optic nerve and concomitant somatic disease play an important role in the choice of the type of treatment. The most informative indices for hospital treatment of patients with cataract after surgery are patient's age, his/her financial status, the number of concomitant somatic and eye diseases.

Keywords: prediction, cataract, out-patient treatment, undetermined logics.

\section{Introduction}

Cataract is the most common cause of blindness in the world. According to modern data cataract is the reason of blindness of over 18 millions of people from different countries all around the world [1]. Modern tendency of population's aging provides the increase of patients' number with cataract, that's why the number of blind people can be more than 40 millions people by 2025 [2]. The number of patients with cataract increased during last decades so the most remarkable growth of the morbidity will be in the nearest future [3]. In countries such as the United States and Great Britain, cataract is still a common cause of visual loss, especially among African Americans and older adults [4]. As the proportion of persons age 60 and older in the world's population increases, a shift in the burden of eye diseases to age-related causes will occur, resulting in cataract accounting for an even greater proportion of visual loss. By the year 2020, the projected numbers of persons with blinding cataract will exceed 40 million worldwide [5]. Over the past few years in many 
countries a number of cataract patients grew significantly, it happened as a result of population ageing [6]. Not looking at substantial progress of cataract surgery, a more considerable increase of morbidity rate is expected in near future. More than $60 \%$ of surgeries, which were done in ophthalmological institutions were made concerning cataract [7]. Quality cataract surgery has been shown to enhance visual function and quality of life.

The modern tendencies of the organization of ophthalmological care to patients with cataract are out-patient treatment or surgery which requires one day [8]. Nowadays, in many countries such approach is the standard way of the treatment of patients with cataract [9]. Out-patient treatment of cataract retracts the necessity in the bedspace, it leads to economy of energy resources and financial resources, and it also decreases emotional, physical and financial costs of patients.

The prevalence rate of cataract in Ukraine includes from 980 to 1200 on 100 thousands of population (based on people who need treatment). Recent statistic shows that more than three millions of citizens' requests for medical care because of eye diseases are registered in Ukraine each year. In the structure of eye morbidity in the past 10 years cataract takes the second place (11\%) after conjunctive diseases $(30,7 \%)[9,10]$. Present social and economic situation in the world is accompanied by the decrease of real incomes, and it can cause the decrease of patient's visit to hospital and increase of cataract rate especially its mature form.

Hospital treatment of cataract is the most important and comfortable one. These factors include patient's age, difficulties with individual movement of patients and far place of residence (for example in region or other town), residence without relatives, care absence, poor financial status, the presence of concomitant somatic pathology and eye disorders, which can cause the development of postoperative complications [11, 12].

Ophthalmological status of the patient plays an important role in the choice of the treatment (out-patient treatment or hospital one), and the presence of concomitant eye diseases which can increase the risk of postoperative complications, the treatment of which will require long-lasting hospital stay [13].

\section{Aim}

To evaluate and prognosticate the duration of hospital treatment of patients with cataract.

\section{Materials and methods of the investigation}

629 case histories of patients with cataract, who took treatment in Kharkiv Municipal Clinical Hospital No 14 in 2014-2015 and took hospital treatment during different period of time, were involved in our investigation. The assessment of case histories was done according to the scheme: sex, age, the stage of cataract, the duration of hospital treatment, the cause of treatment which lasts more than 1 day (postoperative complication, treatment of concomitant eye diseases, patient's desire), the type of complication.

60 surveyed patients with cataract required surgical treatment in order to work out the model of the duration of hospital treatment. The questionnaire contained several questions, answers of which allow evaluating the social status of patients, somatic and optic status, peculiarities of the main disease and also the duration at the hospital after the operation. If the duration at the hospital included 0-1 days, it is considered that an operation was done during one day.

The analysis of patients' questionnaire gave an opportunity to make anamnesis, evaluate somatic status and optic status, social status, finances, place of residence, and its distance from the hospital, and to determine the presence of chronic diseases such as ischemic heart disease, hypertensive disease (high blood pressure), diabetes mellitus, arthropathy, respiratory diseases, thyroid diseases, problems with digestive system, kidney disorders, and other diseases.

The group of patients included 19 men, average age of patients was $(63,7 \pm 16,7)$ and 41 women, average age of females was $(67,6 \pm 10,2)$. Among examined patients $80 \%$ (48 persons) were patients more than 60 years old, $50 \%$ of them ( 24 persons) more than 70 years old.

The received results of case histories of patients were analyzed and processed statistically using the method of expert assessment, analysis of alternative characteristics [14]. 
Undetermined logic was used in order to develop the model of prognosis in need of hospital treatment and its duration based on results of the questionnaires [15]. The model of prognosis of undetermined rules was developed using the method of clustering [16]. Program pack of system of computerized algebra Scilab [17] with pack of extension sciFLT was used to determine tasks of clustering, optimization and undetermined logic conclusion [18, 19].

Corresponding indices were calculated before clustering of these indices which determined patients with cataract and their somatic and optic status. Each disease of the patient had 1 grade. The index of somatic status was calculated as grades of the presence of each concomitant disease. When there is a high index value, the somatic condition of the patient is poor [20]. Optic index was calculated similarly which is equal to grades for each of concomitant diseases.

Three variants of answers were proposed to patients to evaluate and determine financial status. These variants appropriated corresponding grades. Well financial status included 1 grade, satisfactory one included 2 grades, and unsatisfactory status included 3 grades.

Such indices as age, financial status, optic index and index of somatic status determine previous information which was received from questionnaires and case histories of patients with cataract. Such indices also determine the most informative prognosis for the duration of hospital treatment after surgery.

\section{Results}

Table 1 presented patients' division depending on the time of the duration at the hospital. Based on information which is presented in the table 1 it should be noted, that more than $57 \%$ of patients took hospital treatment from 4 to 7 days. $117(19 \pm 1,5) \%$ of patients took out-patient treatment, more than 7 days $75(11 \pm 1,2) \%$ of patients were treated at the hospital. Postoperative complications, cataract with glaucoma, the treatment of vascular malformation are the main causes of long-lasting hospital treatment of patients. Mature age of patients (middle age) was not the cause of long-lasting hospital treatment, so each group contained from 50 to $70 \%$ of people who were 70 years old, and the average age of patients did not differ.

Table 1

Patients' division depending on the duration of hospital treatment

\begin{tabular}{ccccc}
\hline Duration of treatment, day & Number of patients (\%) & Middle & Age \\
Minimal & 39 & 93 \\
\hline 1 & $117(19 \pm 1,5)$ & $68,9 \pm 11,3$ & 40 & 88 \\
$2-3$ & $76(13 \pm 1,3)$ & $69,7 \pm 9,8$ & 35 & 90 \\
$4-7$ & $361(57 \pm 2,0)$ & $72,0 \pm 9,3$ & 40 & 89
\end{tabular}

Received information was used to develop the model of prognosis of the duration of hospital treatment. Diagnostic training sample was formed as rectangular matrix, in which each line contains data of one patient, and columns include such information as: age, financial status, optic index and index of somatic status, the number of days of the hospital treatment.

Well financial status of patients was marked only in $(3,3 \pm 2,2) \%$ of people ( 2 people), satisfactory one was noted in $(70 \pm 5,9) \%$ of patients ( 42 people), poor financial status was marked in $(26,7 \pm 5,7) \%$ of patients (16 people). Financial means determine the opportunity of the person after out-patient treatment visits the hospital in order to take control examination or continue the treatment if it is necessary. As usual patients with poor financial means stay at the hospital where they can receive qualified medical aid, nutrition and care twenty four hours.

Information of case histories was used to calculate the optic index. The presence of myopia alta, glaucoma, diseases of retina, and diseases of optic nerve was indentified in patients. Besides, 
the type of cataract and its stage was also considered. There were $13(21 \pm 5,2) \%$ people with myopia alta, $11(18 \pm 4,9) \%$ - with glaucoma, $9(15 \pm 3,5) \%$ - with diseases of retina, $4(7 \pm 3,3) \%$ - with optic nerve. It has been established, that $31(51 \pm 6,4) \%$ patients did not have eye pathologies concomitant to cataract, $23(38 \pm 6,2) \%$ patients had one disorder, $4(7 \pm 3,3) \%$ patients had two diseases, $2(4 \pm 2,5) \%-$ had concomitant eye diseases. The analysis of the structure of concomitant cataract eye diseases defined that the most widespread pathologies in the group of examined patients were myopia and glaucoma $((39 \pm 6,2) \%$ of the number of examined people).

It has been established, that 9 patients $(16 \%)$ did not have concomitant somatic pathology during calculation of index of somatic status (correspondingly the index was 0 ). One concomitant disease had 8 (13\%) patients, two diseases had 11 (18\%), three diseases had 14 (23\%), four ones $9(16 \%)$, five ones $5(8 \%)$, six and seven diseases had $2(3 \%)$ patients. Consequently, two or more concomitant diseases were present in $71 \%$ of examined patients that indicates the high possibility of the presence of postoperative complications and necessity of the hospital treatment.

After the development of diagnostic training sample, procedure of the synthesis of prognosis model with initial parameters of the algorithm of the clustering was done: radii $=0,5$; accept ratio $=0,5$; reject ratio $=0,15$. In order to decrease the number of rules (it can be due to the decrease of clusters) parameters setting of reject ratio of the algorithm was done. Characteristics of parameters reject ratio (from 0,15 to 0,49 with the step 0,01 ) was increased and procedure of the synthesis of prognosis model was repeated. The main conditions of the setting are: quality degradation of the prognosis to the level of average mistake $\Delta>0,5$ or development of minimal value of rules' number.

The model of prognosis of the number of days in the hospital was received during the work of the procedure, optimal number of clusters and value of average mistake of prognosis $\Delta_{\mathrm{cp}}$. was determined. Optimal parameters of the algorithm of clustering were the next: parameter, which determines sizes of clusters (radii) $=0,5$; coefficient of suppression $=1,25$; coefficient of acceptance (accept ratio) $=0,5$ coefficient of rejection (reject ratio) $=0,4$.

Next approach was used to evaluate adequacy of developed model of prognosis: one line was elicited from training sample, which corresponds to the information of concrete patient, the model was synthesized again and expected number of days in the hospital for each set of indices was calculated according to it. Such control determined that number of days which patients were in the hospital and received in the result of the developed model of prognosis referred to it sufficiently well.

It is necessary for the physician to set up system Scilab with the pack of extension sciFLT and save on HD the file with developed model of the duration of hospital treatment ("prediction_model.fls" for practical use of received undetermined model. After that, patients' data that required surgical treatment of cataract is involved in the installed program and the duration in the hospital is calculated.

\section{Discussion}

Out-patient treatment of cataract retracts the necessity in the bedspace, it leads to economy of energy resources and financial resources, and it also decreases emotional, physical and financial costs of patients. Otherwise, the peculiarity of Ukrainian system of Healthcare, financial funding of medical institutions and medical and social peculiarities of patients with cataract (age, the presence of pathology, financial status, the place of residence) define not always out-patient treatment as accessible one. So, the choice of out-patient treatment or hospital one is accompanied by medical and social causes, which should be considered during the first ophthalmological aid to patients with cataract.

Developed model of the prognosis of the duration of hospital treatment can be used to maintain making decision according to treatment management of concrete patient with cataract. A doctor should propose hospital treatment to patient during predictive term more than 1 day or when patient chooses out-patient treatment it is necessary to define the possible risk of the presence of postoperative complications, which can be associated with complications of optic and somatic status of the patient. 


\section{Conclusions}

1. Mature patient's age (middle age), difficulties with individual movement, the place of residence, living without relatives, poor financial status of the patient, the presence of concomitant somatic disease or eye pathology are the main limits for out-patient treatment.

2. Ophthalmologic status of the patient, the presence of concomitant eye diseases, such as myopia alta, glaucoma, diseases of retina, and optic nerve play an important role in the choice of the type of treatment.

3. The most informative indices for hospital treatment of patients with cataract after surgery are patient's age, his/her financial status, the number of concomitant somatic and eye diseases.

4. Program pack of system of computerized algebra Scilab with pack of extension sciFLT can be used to determine tasks of clustering, optimization and undetermined logic which allow predicting the duration of hospital treatment of patients with cataract.

The prospect for further investigations is the development of measures in order to improve results of cataract treatment and contract the time of duration at the hospital with developed model of prognosis of the duration of hospital treatment.

\section{References}

[1] Veselovskaya, Z. F., Blyumental, M. I., Bobrova, N. F. (2002). Katarakta. Kyiv: Kniga plyus, 208.

[2] Katarakta. Adaptovana klinichna nastanova, zasnovana na dokazah (2015). Available at: http:// mtd.dec.gov.ua/images/dodatki/2016_49_Katarakta/2016_49_AKN_Katarakta.pdf

[3] Korsakova, N. V., Pashtaev, N. P., Sergeeva, V. E., Pozdeeva, N. A. (2012). Sovremennyie aspektyi patogeneza vozrastnoy kataraktyi cheloveka (obzor literaturyi). Oftalmohirurgiya, 2, 82-85.

[4] Abraham, A. G., Condon, N. G., West, G. E. (2006). The new epidemiology of cataract. Ophthalmol Clin North Am., 19 (4), 415-425.

[5] Chitkara, D. K., Hall, A. B., Rosental, A. R. (2011). Pathophysiology and Epidemiology of Cataract. Free Medical Textbook. Chapter 35. Available at: https://medtextfree.wordpress.com/category/ophthalmology/page/2/

[6] Robertson, S. (2015). Cataract Epidemiology. Available at: http://www.news-medical.net/health/ Cataract-Epidemiology.aspx

[7] Kovtun, M. I. (2016) Assessment result of cataract stages distribution and concomitant diseases structure. East European Scientific Journal, 1 (6), 48-52.

[8] UnIfikovaniy klinichniy protokol pervinnoyi, vtorinnoyi (spetsializovanoyi), tretinnoyi (visokospetsializovanoyi) medichnoyi dopomogi. katarakta (2016). Nakaz MOZ Ukrayini vid 28.01.2016, \# 49. Available at: http://www.moz.gov.ua/ua/portal/dn_20160128_0049.html

[9] Organizatsiya oftalmologichnoyi dopomogi na suchasnomu etapi (2008). Kyiv: Doktor media, 357.

[10] Slipota ta slabkozorist. shlyahi profilaktiki v ukrayini (2011). Kyiv: TOV «Doktor-MedIa», 268.

[11] Kovtun, M. I. (2015). Mediko-sotsialnaya harakteristika bolnyih kataraktoy Vestnik problem biologii i meditsinyi, 2 (3 (120)), 135-139.

[12] Kovtun, M. I. (2015). Osobennosti organizatsii oftalmologicheskoy pomoschi bolnyim kataraktoy $\mathrm{v}$ usloviyah reformirovaniya sistemyi zdravoohraneniya v Ukraine. Arhiv oftalmologiyi Ukrayini, 3 (2), 14-19.

[13] Kovtun, M. I. (2012). Rezultatyi otsenki strukturyi soputstvuyuschey zabolevaemosti bolnyih kataraktoy. Vestnik problem biologii i meditsinyi, 4 (1 (96)), 120-124.

[14] Lakin, G. F. (1990). Biometriya. Moscow: Vyisshaya shkola, 352.

[15] Leonenkov, A. V. (2005). Nechetkoe modelirovanie v srede MATLAB i fuzzy TECH. SPb: BHV-Peterburg, 736.

[16] Yager, R., Filev, D. (1994). Essential of Fuzzy Modeling and Control. John Willey \& Sons, 388.

[17] Open source software for numerical computation. Available at: http://www.scilab.org/

[18] Fuzzy Logic Toolbox. Available at: https://atoms.scilab.org/toolboxes/sciFLT

[19] Shtovba, S. D. (2007). Proektirovanie nechetkih sistem sredstvami MATLAB. Moscow: Goryachaya liniya - Telekom, 288.

[20] Kovtun, M. I. (2012). Analiz gendernyih osobennostey srokov obrascheniya za hirurgicheskoy pomoschyu pri katarakte. Vestnik problem biologii i meditsinyi, 4, 2 (97), 91-95. 